\title{
Efektivitas Air Perasan Kulit Jeruk Manis sebagai Larvasida Nyamuk Aedes aegypti
}

\author{
Effectivity of Sweet Orange Peel Juice as a Larvasides of Aedes aegypti \\ Mosquito
}

\author{
Dita Nurhaifah, Tri Wahyuni Sukesi
}

\author{
Program Studi Ilmu Kesehatan Masyarakat Fakultas Kesehatan Masyarakat Universitas Ahmad Dahlan
}

\begin{abstract}
Abstrak
Demam berdarah dengue ditularkan nyamuk Aedes aegypti yang dapat dicegah dengan temefos. Penggunaan yang berkelanjutan berdampak pada resistensi nyamuk dan kerusakan lingkungan. Untuk itu perlu larvasida alami dengan menggunakan air perasan kulit jeruk manis. Tujuan penelitian untuk membuktikan efektivitas air perasan kulit jeruk manis dalam membunuh larva uji dilihat dari nilai $\mathrm{LC}_{50}$ dan $\mathrm{LT}_{50}$ serta perbedaan efektivitasnya dengan temefos. Sampel 25 larva Aedes aegypti setiap gelas media dengan kriteria inklusi instar III yang aktif dan kriteria eksklusi larva instar I, II dan yang telah menjadi pupa/mati. Larva uji diamati selama 24 jam dengan tiga kali pengulangan. Desain penelitian adalah eksperimental murni. Tempat penelitian di Laboratorium Entomologi Universitas Ahmad Dahlan pada Juni 2014. Larvasida alami dibuat dengan menghaluskan kulit jeruk manis dan disaring sampai diperoleh sarinya. Konsentrasi yang digunakan adalah $0,05 \% ; 0,2 \% ; 0,4 \% ; 0,6 \% ; 0,8 \% ; 1 \% ; 1,2 \%$; dan 1,4\%. Penetapan konsentrasi berdasarkan pada uji pendahuluan, kematian larva tertinggi pada konsentrasi $1 \%$ dan terendah pada $0 \%$. Pengolahan data dengan analisis regresi linear dan regresi probit. Air perasan kulit jeruk manis efektif sebagai larvasida nyamuk Aedes aegypti. Nilai LC $_{50}$ adalah 0,731\% dan nilai $\mathrm{LT}_{50}$ adalah 13.211 jam. Kelompok perlakuan yang dibandingkan dengan temfos (kontrol positif) menghasilkan perbedaan yang signifikan pada konsentrasi $0,05 \% ; 0,2 \% ; 0,4 \%$ dan $0,6 \%$.

Kata kunci: Aedes aegypti, air perasan jeruk manis, larvasida
\end{abstract}

\section{Abstract}

Dengue hemorrhagic fever is transmitted by Aedes aegypti mosquito that can be prevented with temefos. Sustainable use affects on mosquito resistance and environmental damage. Therefore, it needs natural larvasides by using sweet orange peel juice. The study aimed to prove the effectivity of sweet orange peel juice in killing test larvae seen from the $L_{50}$ and $L_{50}$ value as well as any difference of its effectivity with temefos. Samples were 25 Aedes aegypti larvae in each glass medium active instar III inclusion cri- terion and instar I, II, and which had become pupa / die exclusion criteria. Tested larvae were observed for 24 hours with three times repetition. The study desaign was true experimental. The place of study was in Entomology Laboratory of Universitas Ahmad Dahlan on June 2014. Natural larvasides was made from sweet orange peel juice. Concentration used was of $0.05 \%$, $0.2 \%, 0.4 \%, 0.6 \%, 0.8 \%, 1 \%, 1.2 \%$, and $1.4 \%$. Determination of concentration based on preliminary test where the highest larva mortality $1 \%$ and the lowest at $0 \%$. Processing of data was conducted using linear regression analysis and probit regression. Juice of sweet orange peel was effective as the Aedes aegypti mosquito larvicides. $\mathrm{LC}_{50}$ value was $0,731 \%$ and $\mathrm{LT}_{50}$ value was 13.211 hours. Group of treatment compared to temfos (control positive) resulted a significant difference in the concentration of $0.05 \%$, $0.2 \%, 0.4 \%$, and $0.6 \%$.

Keywords: Aedes aegypti, sweet orange peel juice, larvicides

\section{Pendahuluan}

Kasus demam dengue dan demam berdarah dengue (DBD) meningkat insiden dan distribusi sepanjang 40 tahun terakhir. Setiap tahun, diperkirakan terdapat 20 juta kasus infeksi dengue dan menyebabkan kira-kira 24 juta kematian. ${ }^{1}$ DBD adalah penyakit demam akut disebabkan oleh empat serotipe virus dari Genus Flavivirus, virus RNA dari keluarga Flaviridae. Dengue ditularkan oleh genus Aedes, nyamuk yang tersebar di daerah tropis dan subtropis di seluruh dunia. ${ }^{2}$ Host alami DBD adalah manusia, agennya adalah virus dengue. ${ }^{3}$

Pada tahun 2013, jumlah penderita DBD yang dilaporkan sebanyak 112.511 kasus dengan jumlah kematian

Korespondensi: Tri Wahyuni Sukesi, Prodi Ilmu Kesehatan Masyarakat, FKM Universitas Ahmad Dahlan, Jl. Prof. Dr. Soepomo, Janturan, Umbulharjo, Yogyakarta, No. Telp: 0274-563515, e-mail: yunisukesi.fkmuad@gmail.com 
871 orang (angka kesakitan $=45,85$ per 100.000 penduduk dan angka kematian $=0,77 \%$ ). Terjadi peningkatan jumlah kasus pada tahun 2013 dibandingkan tahun 2012, terdapat 90.245 kasus dengan angka kesakitan sebesar 37,27 per 100.000 penduduk. ${ }^{4}$ Untuk mencegah penularan virus $\mathrm{DBD}$ adalah dengan pemberantasan nyamuk Aedes aegypti baik pemberantasan secara fisik, biologi, maupun kimiawi. ${ }^{5}$ Contoh pengendalian secara kimiawi adalah penyemprotan insektisida di fokus area dan pembagian bubuk abate. ${ }^{6}$

Selama ini, pemerintah menyarankan kepada masyarakat untuk menggunakan bubuk abate (temefos) sebagai salah satu upaya pengendalian vektor DBD. Namun, penggunaan temefos secara terus menerus dalam pengendalian vektor memungkinkan timbulnya resistensi terhadap larvasida tersebut karena sifat transovarial dari nyamuk. ${ }^{7}$ Tidak hanya itu, penggunaan pestisida sintetis yang intensif dapat menimbulkan pencemaran dan berdampak negatif pada kesehatan manusia, misalnya tertelan akan memicu keracunan. ${ }^{8,9}$ Banyaknya dampak negatif penggunaan pestisida sintetis mendorong penelitian mengenai larvasida alami, salah satunya dari buah jeruk dari berbagai spesies. Buah jeruk dipilih karena memiliki senyawa kimia yang memiliki aktivitas biologis, seperti flavonoid, karotenoid, dan limonoid. ${ }^{10}$ Penelitian mengenai pemanfaatan tanaman jeruk sudah banyak dilakukan, Bilal dkk, ${ }^{11}$ yang telah memanfaatkan jeruk lemon sebagai larvasida nyamuk Aedes albopictus dengan nilai $\mathrm{LC}_{50}$ pada 377,4 ppm dan nilai $\mathrm{LT}_{50}$ pada jam ke-31.

Berdasarkan skrining fitokimia yang dilakukan Oluremi dkk, 12 menunjukkan bahwa kulit jeruk mengandung tanin, saponin, fitat oksalat, flavonoid, dan limonoid. Limonoid memiliki kemampuan untuk menghambat pembentukan sel kanker, mengurangi pembentukan low-density lipoprotein (LDL) serta berdasarkan uji lapangan yang dilakukan pada serangga, limonoid mampu menghambat serangga untuk makan (antifeedant). ${ }^{13}$ Saponin adalah senyawa aktif permukaan yang kuat yang menimbulkan busa bila dikocok dalam air dan dalam konsentrasi rendah dapat menimbulkan hemolisis sel darah merah. ${ }^{14}$ Cara kerja saponin yang diekstrak dari berbagai tanaman memiliki efek gangguan tahap perkembangan dan gangguan pergantian kulit (molting). Pada stadium larva Culex fatigan menunjukkan pigmentasi yang parah serta kerusakan bentuk kepala dan perut. ${ }^{15}$

Penelitian mengenai air perasan kulit jeruk manis sebagai larvasida, sebelumnya pernah dilakukan oleh Wati, ${ }^{16}$ nilai $\mathrm{LC}_{50}$ dari larvasida alami air perasan kulit jeruk manis yang diperoleh adalah $0,946 \%$. Dalam penelitian tersebut, belum diperoleh nilai $\mathrm{LT}_{50}$ dari larvasida alami air perasan kulit jeruk manis sehingga peneliti juga merasa perlu melakukan penelitian larvasida dari air perasan kulit jeruk manis untuk mengetahui nilai
$\mathrm{LT}_{50}$.

Berdasarkan latar belakang tersebut, penelitian ini dilakukan untuk membuktikan efektivitas air perasan kulit jeruk manis sebagai larvasida dengan melihat nilai $\mathrm{LC}_{50}$ dan $\mathrm{LT}_{50}$ air perasan kulit jeruk manis dalam membunuh larva Aedes aegypti serta membandingkan efektivitas air perasan kulit jeruk manis dengan temefos sebagai larvasida.

\section{Metode}

Penelitian ini merupakan penelitian eksperimental murni. Desain eksperimen yang digunakan adalah post test only control group design. Pada rancangan ini, peneliti membandingkan jumlah larva yang mati antara penggunaan temefos dengan larvasida alami dari air perasan kulit jeruk manis dalam berbagai konsentrasi. Total larva Aedes aegypti yang digunakan adalah 25 ekor per gelas. Dalam gelas uji, media yang digunakan adalah air sebanyak $100 \mathrm{~mL}$ maka dimasukkan 25 larva uji dalam setiap gelas media agar kondisi media tidak terlalu padat di samping itu, jumlah tersebut juga sudah menjadi standar dari WHO. Kriteria inklusi yang ditetapkan adalah larva Aedes aegypti instar III yang masih bergerak aktif. Kriteria eksklusi yang ditetapkan adalah larva Aedes aegypti larva instar I dan II, larva yang mati dan larva yang berubah menjadi pupa. Pengamatan terhadap penelitian ini dilakukan secara observasi langsung dengan cara mencatat waktu, konsentrasi yang mampu membunuh dan jumlah larva uji yang mati. Penelitian ini dilakukan di Laboratorium Entomologi Fakultas Kesehatan Masyarakat Universitas Ahmad Dahlan pada bulan Juni 2014.

Bahan yang digunakan dalam penelitian ini adalah kulit buah jeruk manis. Dalam pembuatan air perasan kulit jeruk manis, peneliti membuat larutan stok 25\% yang diencerkan dengan air keran dari Rumus 1.

Sebelum melakukan pengenceran air perasan kulit jeruk manis sesuai dengan konsentrasi yang diperlukan, peneliti terlebih dahulu membuat larutan stok dengan konsentrasi 25\% dengan cara kulit jeruk manis sebelum dikupas dicuci terlebih dahulu, selanjutnya dianginanginkan. Setelah kering, selanjutnya dikupas dan diiris tipis dengan maksud mempermudah dalam menghaluskan kulit jeruk manis. Kemudian peneliti menimbang 25 gram kulit jeruk yang sudah diiris tipis. Sebanyak 25 gram kulit jeruk tersebut dihaluskan menggunakan blender dengan menambahkan $100 \mathrm{~mL}$ air, sehingga

Rumus 1.

$\mathrm{V}_{1} \mathrm{M}_{1}=\mathrm{V}_{2} \mathrm{M}_{2}$

Keterangan:

$\mathrm{V}_{1}$ : volume larutan mula-mula

$\mathrm{M}_{1}$ : konsentrasi larutan mula-mula

$\mathrm{V}_{2}$ : volume larutan seteah diencerkan

$\mathrm{M}_{2}$ : konsentrasi larutan setelah diencerkan 
diperoleh larutan stok sebanyak 25\% air perasan kulit jeruk manis.

Berdasarkan rumus di atas, konsentrasi yang digunakan dalam uji pendahuluan adalah $1 \%, 2 \%, 3 \%, 4 \%$, dan $5 \%$. Hasil yang diperoleh dalam uji pendahuluan adalah bahwa pada konsentrasi $1 \%$ larva uji sebanyak 25 ekor sudah mati semua (kematian 100\%). Begitu pula pada konsentrasi 2\%, 3\%, 4\%, dan 5\%. Semua larva uji sudah mati kurang dari 24 jam. Pada uji sebenarnya, konsentrasi yang digunakan peneliti adalah konsentrasi di bawah $1 \%$ yaitu $0,05 \%, 0,2 \%, 0,4 \%, 0,6 \%, 0,8 \%, 1 \%$, $1,2 \%$, dan $1,4 \%$.

Jumlah larva Aedes aegypti per gelas media yang digunakan dalam penelitian ini adalah 25 ekor larva sesuai dari standar World Health Organization (WHO). ${ }^{1}$ WHO dalam Dengue: Guidelines for diagnosis, treatment, prevention and control menyatakan bahwa jumlah larva yang digunakan dalam penelitian adalah sebanyak 25 ekor larva. Selain merupakan standar dari WHO, alasan peneliti menggunakan 25 ekor larva bersifat teknis karena media yang digunakan adalah gelas yang berisi 100 $\mathrm{mL}$ air. Apabila media diisi lebih dari 25 ekor, kematian larva bisa karena faktor kepadatan dalam media. Kontrol positif dalam penelitian ini adalah air sumur, sedangkan kontrol negatif dalam penelitian ini adalah temefos. Kontrol positif berupa air sumur digunakan dengan alasan bahwa kematian larva uji benar karena pengaruh pemberian larvasida alami air perasan kulit jeruk manis, sedangkan kontrol negatif berupa temefos dimaksudkan untuk melihat dan membandingkan keefektifan larvasida alami dalam membunuh larva uji.

Peneliti selanjutnya membuat larutan air perasan kulit jeruk manis dengan konsentrasi yang ditetapkan di atas sebanyak $100 \mathrm{~mL}$. Jumlah larutan $100 \mathrm{~mL}$ tersebut dimasukkan ke dalam gelas plastik. Setelah media uji siap, peneliti memasukkan larva Aedes aegypti stadium III sebanyak 25 ekor. Alasan peneliti menggunakan larva Aedes aegypti stadium III adalah larva karena instar III ukurannya sudah cukup besar sehingga mudah untuk diidentifikasi serta larva instar III merupakan sampel penelitian yang menjadi standar dari WHO. Setelah larva dimasukkan ke dalam media uji, selanjutnya peneliti mengamati dan menghitung jumlah kematian larva uji sampai 24 jam. Apabila setelah 24 jam 50\% larva uji belum mati, maka peneliti dapat menambah waktu pengamatan sampai 48 jam dan seterusnya sampai maksimal 96 jam karena jika lebih dari 96 jam kematian larva dapat disebabkan faktor lain. Selain itu, dikhawatirkan larva sudah berubah stadium menjadi pupa sehingga penelitian harus diulang kembali. Penelitian ini dilakukan dalam tiga replikasi/ulangan. Dalam penelitian ini, salah satu variabel pengganggu adalah suhu, karena suhu akan memengaruhi kondisi biologis larva. Apabila suhu tidak dikontrol menjadi suhu ruang- an normal, dikhawatirkan larva uji mati bukan karena larvasida alami yang diberikan melainkan karena suhu yang terlalu ekstrem baik itu terlalu tinggi ataupun terlalu rendah. Maka, peneliti memutuskan untuk mengontrol dengan mengatur suhu kamar menjadi $27^{\circ} \mathrm{C}$.

Instrumen penelitian dalam penelitian ini adalah timbangan analitik, blender, saringan, akuades, tisu, batang pengaduk untuk pembuatan air perasan kulit jeruk manis, labu ukur, propipet, corong buchner, mikropipet, batang pengaduk, gelas plastik, ose jarum, dan senter untuk alat uji larvasida. Data yang dicatat peneliti adalah kematian larva pada masing-masing media uji selama 24 jam pada pengamatan jam ke-1, 2, 3, 4, 6, 8, 12, 16, 20 dan 24. Setelah diperoleh data kematian larva Aedes aegypti, selanjutnya peneliti melakukan analisis data. Analisis data dalam penelitian ini ada dua yaitu analisis regresi linier dan analisis regresi probit. Pada analisis regresi linier untuk mengetahui sebaran data normal atau tidak menggunakan uji Saphiro wilk karena jumlah sampelnya $<50$. Dilanjutkan dengan uji Levene untuk mengetahui varian datanya homogen atau tidak. Apabila distribusi datanya normal dan varianya homogen maka dilanjutkan analisis varian dengan uji anova satu arah dilanjutkan uji Turkey, tetapi apabila syarat tersebut tidak terpenuhi maka analisis dengan uji Kruskal Wallis dilanjutkan Uji Mann Whitney.

\section{Hasil}

Berdasarkan Tabel 1 dapat dilihat jumlah dan presentase kematian larva Aedes aegypti yang diberi perlakuan, yaitu dengan menambahkan air perasan kulit jeruk manis konsentrasi $0,05 \%, 0,2 \%, 0,4 \%, 0,6 \%$, $0,8 \%, 1 \%, 1,2 \%$, dan $1,4 \%$. Hasil uji sebenarnya diperoleh hasil bahwa air perasan kulit jeruk manis pada konsentrasi $1 \%$ dan $1,4 \%$ sudah mampu membunuh larva Aedes agypti sebanyak 100\% dan konsentrasi terendah yang tidak mampu membunuh larva Aedes aegypti adalah 0,05\%, yaitu tidak terdapat kematian.

Berdasarkan Tabel 2 kita dapat melihat hasil analisis regresi yang masing-masing nilai memiliki makna. Nilai $\mathrm{R}$ dapat menunjukkan tingkat hubungan antar variabel bebas dengan variabel terikat, nilai $\mathrm{R}^{2}$ menunjukkan pengaruh perlakuan. Hasil uji regresi diperoleh nilai $\mathrm{R}$ sebesar 782, artinya korelasi variabel bebas dan terikat memiliki hubungan sangat erat karena mendekati angka 1. Nilai $R^{2}$ sebesar 612 artinya pengaruh pemberian air perasan kulit jeruk manis dalam membunuh larva uji sebesar $61 \%$, sisanya dipengaruhi variabel lain.

Berdasarkan Tabel 3, kita dapat mengetahui nilai mean masing-masing perlakuan dari kontrol negatif, konsentrasi $0,05 \%, 0,2 \%, 0,4 \%, 0,6 \%, 0,8 \%, 1 \%, 1,2 \%$, dan 1,4\%. Tabel 3 menunjukkan nilai rata-rata dari masing-masing variabel. Data yang digunakan dalam bentuk numerik sehingga dapat diketahui nilai rata-rata masing- 
Tabel 1. Jumlah dan Presentase Larva Aedes aegypti yang Mati Setelah Pemberian Air Perasan Kulit Jeruk Manis Selama 24 Jam pada Uji Sesungguhnya

\begin{tabular}{llllll}
\hline & \multicolumn{2}{c}{ Jumlah Kumulatif Kematian Larva } & & \\
\cline { 2 - 3 } Kelompok Perlakuan & \multicolumn{2}{c}{ Pengulangan } & & $\begin{array}{c}\text { Rata-rata } \\
\text { Kematian (ekor) }\end{array}$ & $\begin{array}{c}\text { Persentase } \\
\text { Kematian (\%) }\end{array}$ \\
\cline { 2 - 3 } & I & II & III & & \\
\hline Konsentrasi 0,05\% & 0 & 0 & 0 & 0 & 0 \\
Konsentrasi 0,2\% & 18 & 12 & 13 & 14,33 & 57,32 \\
Konsentrasi 0,4\% & 21 & 21 & 20 & 20,66 & 82,64 \\
Konsentrasi 0,6\% & 24 & 23 & 24 & 23,66 & 94,64 \\
Konsentrasi 0,8\% & 25 & 24 & 24 & 24,33 & 97,32 \\
Konsentrasi 1 \% & 25 & 25 & 25 & 25 & 100 \\
Konsentrasi 1,2\% & 25 & 25 & 24 & 24,66 & 98,64 \\
Konsentrasi 1,4\% & 25 & 25 & 25 & 25 & 100 \\
Kontrol positif & 25 & 25 & 25 & 25 & 100 \\
Kontrol negatif & 0 & 0 & 0 & 0 & 0 \\
\hline
\end{tabular}

Tabel 2. Hasil Analisis Regresi untuk Mengetahui Pengaruh Konsentrasi Air Perasan Kulit Jeruk Manis dengan Kematian Larva Uji

\begin{tabular}{lccc}
\hline Model & $\mathbf{r}$ & $\mathbf{R}^{\mathbf{2}}$ & Nilai $\mathbf{p}$ \\
\hline $\begin{array}{l}\text { Konsentrasi air perasan } \\
\text { kulit jeruk manis }\end{array}$ & 0,782 & 0,612 & 0,000 \\
\hline
\end{tabular}

Tabel 3. Hasil Uji Kruskal Wallis untuk Mengetahui Nilai Rata-rata Masingmasing Perlakuan

\begin{tabular}{lllc}
\hline Model & Perlakuan & n & Rata-rata Ranking \\
\hline Mortalitas larva & Kontrol negatif & 3 & 3,50 \\
& 0,05 & 3 & 3,50 \\
& 0,2 & 3 & 8,00 \\
& 0,4 & 3 & 11,00 \\
& 0,6 & 3 & 15,00 \\
& 0,8 & 3 & 18,83 \\
& 1 & 3 & 24,50 \\
& 1,2 & 3 & 21,70 \\
& 1,4 & 3 & 24,50 \\
Total & Kontrol positif & 3 & 24,50 \\
\hline
\end{tabular}

masing konsentrasi. Nilai rata-rata tertinggi terdapat pada konsentrasi $1 \%, 1,4 \%$ dan kontrol positif, sedangkan nilai rata-rata terendah pada konsentrasi $0,05 \%$.

Pada Tabel 4 kita dapat melihat adanya perbedaan kematian larva antara perlakuan pemberian air perasan kulit jeruk manis dibandingkan dengan temefos dan air sumur.

Hasil uji Kruskal Wallis dilakukan untuk mengetahui perbedaan antar perlakuan dengan rata- rata jumlah kumulatif kematian larva. Dari hasil uji tersebut didapatkan nilai $\mathrm{p}$ sebesar 0,001 . Artinya, ada perbedaan rata-rata jumlah kumulatif kematian larva Aedes aegypti menggunakan air perasan kulit jeruk manis, temefos, dan air keran. Untuk mengetahui kelompok mana yang mempunyai perbedaan, dilakukan uji Mann Whitney.

Hasil uji Mann Whitney, dapat diketahui perbedaan antara dua perlakuan. Jika kelompok perlakuan diban- dingkan dengan kelompok kontrol positif (temefos $0,01 \%$ ), maka diketahui hasil yang memiliki perbedaan signifikan adalah konsentrasi $0,05 \%, 0,2 \%, 0,4 \%$, dan $0,6 \%$. Perlakuan pada konsentrasi $0,8 \%, 1 \%, 1,2 \%$, dan $1,4 \%$ tidak memiliki perbedaan yang signifikan. Sedangkan, perbedaan antara kontrol negatif (air keran) dengan perlakuan yang hasilnya tidak ada perbedaan adalah konsentrasi 0,05\% sementara konsentrasi lain terdapat perbedaan.

Berdasarkan Tabel 5 kita dapat mengetahui perbedaan dari rata-rata kematian larva pada masing-masing perlakuan, yaitu dengan pemberian kontrol positif, kontrol negatif, maupun pemberian air perasan kulit jeruk manis pada masing-masing konsentrasi. Berdasarkan Tabel 5 dapat diketahui nilai $\mathrm{L}_{50}$ pada setiap ulangan dan rata-rata nilai $\mathrm{LC}_{50}$ air perasan kulit jeruk manis terhadap kematian larva Aedes aegypti. Hasil analisis regresi diperoleh rata-rata $\mathrm{LC}_{50}$ pada konsentrasi $0,731 \%$ dalam kisaran konsentrasi 0,560\% - 0,921\%. Berdasarkan analisis probit, diperoleh rata-rata $\mathrm{LT}_{50}$ pada jam ke-13.211 dalam kisaran waktu 10.314 - 16.597 jam

\section{Pembahasan}

Larvasida alami yang digunakan adalah air perasan kulit jeruk manis. Sebelum melakukan uji sebenarnya, peneliti melakukan uji pendahuluan dengan konsentrasi $1 \%, 2 \%, 3 \%$, $4 \%$, dan $5 \%$. Dari uji pendahuluan diperoleh konsentrasi yang akan digunaan pada uji sebenarnya, yaitu $0,05 \%, 0,2 \%, 0,4 \%, 0,6 \%, 0,8 \%, 1 \%, 1,2 \%$, dan $1,4 \%$.

Berdasarkan pengamatan yang dilakukan dapat dilihat konsentrasi air perasan kulit jeruk manis terendah yang dapat menimbulkan kematian larva uji adalah konsentrasi $0,2 \%$ dengan persentase $57,32 \%$. Selain itu, dapat dilihat bahwa pada kelompok kontrol negatif (air keran) tidak terdapat larva uji yang mati. Sedangkan pada kontrol positif terdapat 100\% kematian larva uji. Hal ini 


\begin{tabular}{|c|c|c|c|c|c|c|c|c|c|c|}
\hline & \multicolumn{7}{|c|}{ Konsentrasi air perasan kulit jeruk manis } \\
\cline { 2 - 10 } & K- & $\mathbf{0 , 0 5}$ & $\mathbf{0 , 2}$ & $\mathbf{0 , 4}$ & $\mathbf{0 , 6}$ & $\mathbf{0 , 8}$ & $\mathbf{1}$ & $\mathbf{1 , 2}$ & $\mathbf{1 , 4}$ & $\mathrm{K}+$ \\
\hline $\mathrm{K}-$ & & 1.000 & 0.037 & 0.034 & 0.034 & 0.034 & 0.025 & 0.034 & 0.025 & 0.025 \\
\hline $\mathbf{0 , 0 5}$ & & & 0.037 & 0.034 & 0.034 & 0.034 & 0.025 & 0.034 & 0.025 & 0.025 \\
\hline $\mathbf{0 , 2}$ & & & & 0.046 & 0.046 & 0.046 & 0.037 & 0.046 & 0.034 & 0.037 \\
\hline $\mathbf{0 , 4}$ & & & & & 0.043 & 0.043 & 0.034 & 0.043 & 0.034 & 0.034 \\
\hline $\mathbf{0 , 6}$ & & & & & & 0.197 & 0.034 & 0.099 & 0.034 & 0.034 \\
\hline $\mathbf{0 , 8}$ & & & & & & & 0.114 & 0.456 & 0.114 & 0.114 \\
\hline $\mathbf{1}$ & & & & & & & & 0.317 & 1.000 & 1.000 \\
\hline $\mathbf{1 , 2}$ & & & & & & & & & 0.317 & 0.317 \\
\hline $\mathbf{1 , 4}$ & & & & & & & & & & 1.000 \\
\hline $\mathrm{K}+$ & & & & & & & & & & \\
\hline
\end{tabular}

Gambar 1. Hasil Uji Mann Whitney

Tabel 5. Nilai LC $_{50}$ Air Perasan Kulit Jeruk Manis dalam Membunuh Larva Aedes aegypti

\begin{tabular}{llc}
\hline Model & Ulangan & LC $_{\mathbf{5 0}}(\%)$ \\
\hline LC $_{50}$ Air perasan kulit jeruk manis & I & 0,724 \\
& II & 0,741 \\
& III & 0,728 \\
& Rata-rata & 0,731 \\
\hline
\end{tabular}

Tabel 6. Nilai LT $_{50}$ Air Perasan Kulit Jeruk Manis dalam Membunuh Larva Aedes aegypti

\begin{tabular}{lll}
\hline Model & Ulangan & LT $_{\mathbf{5 0}}(\%)$ \\
\hline LT $_{50}$ Air perasan kulit jeruk manis & I & 13,012 \\
& II & 13,402 \\
& III & 13,219 \\
& Rata-rata & 13,211 \\
\hline
\end{tabular}

membuktikan bahwa memang ada pengaruh pemberian air perasan kulit jeruk manis terhadap kematian larva Aedes aegypti. Tingginya angka kematian larva uji dapat disebabkan oleh adanya kandungan senyawa kimia pada kulit jeruk manis yang berperan dalam aktivitas biologis pada pertumbuhan dan perkembangan larva. Berbagai jenis tanaman telah diketahui mengandung senyawa bioaktif seperti fenilpropan, terpenoid, alkaloid, asetogenin, steroid dan tanin yang bersifat sebagai insektisida. ${ }^{17}$ Senyawa yang terkandung dalam kulit jeruk antara lain limonoid, flavonoid, saponin dan tannin. ${ }^{12-15}$ Limonoid dan saponin berperan sebagai penghambat makan pada serangga (antifeedant), flavonoid bekerja untuk melayukan saraf pada sistem pernafasan serangga dan tannin dapat memengaruhi kegagalan moulting pada larva sehing- ga mati sebelum berkembang menjadi pupa. ${ }^{18}$

Analisis probit diketahui bahwa rata-rata nilai $\mathrm{LC}_{50}$ dari konsentrasi air perasan kulit jeruk manis adalah $0,731 \%$. Artinya konsentrasi air perasan kulit jeruk manis dapat membunuh $50 \%$ dari total larva uji pada konsentrasi $0,731 \%$ pada interval $0,560 \%$ dan $0,921 \%$. Pada penelitian yang dilakukan Wati, ${ }^{16}$ yang sama-sama menggunakan air perasan kulit jeruk manis diperoleh nilai $\mathrm{LC}_{50}$ pada konsentrasi $0,946 \%$ pada interval 0,763\% dan $1,117 \%$. Sedangkan, nilai $\mathrm{LC}_{50}$ pada temefos sebesar $0,177 \% .{ }^{19}$ Artinya kemampuan temefos dalam membunuh larva Aedes aegypti lebih baik dibandingkan dengan air perasan kulit jeruk manis (Citrus sinensis), tetapi penggunaan temefos yang terlalu sering dapat menimbulkan efek yang tidak baik bagi kesehatan manusia dan bagi kelestarian lingkungan. Semakin rendah nilai $\mathrm{LC}_{50}$ suatu larvasida alami maka, semakin baik pula efektivitas larvasida tersebut karena dengan jumlah bahan baku yang sedikit dapat menghasilkan daya larvasida yang tinggi. Selain itu, larvasida tersebut ramah lingkungan karena tidak meninggalkan residu pada lingkungan.

Hasil analisis probit nilai $\mathrm{LT}_{50}$ tersebut terlihat bahwa untuk membunuh larva Aedes aegypti dari populasi sampel air perasan kulit jeruk manis pada ulangan pertama adalah selama 13.012 jam, ulangan kedua 13.402 jam dan ulangan ketiga 13.219 jam. Dari hasil tersebut diperoleh rata-rata $\mathrm{LT}_{50}$ air perasan kulit jeruk manis yang mampu membunuh larva Aedes aegypti adalah selama 13.211 jam. Artinya, waktu yang dibutuhkan air perasan kulit jeruk manis dapat membunuh 50\% dari total larva uji adalah selama 13.211 jam pada interval 10.314 jam 
dan 16.597 jam. Nilai $\mathrm{LT}_{50}$ adalah sebuah periode yang dihitung dalam waktu ketika bahan kimia dengan konsentrasi tertentu diperkirakan mampu menyebabkan kematian dari $50 \%$ populasi hewan percobaan. ${ }^{20}$ Semakin rendah nilai $\mathrm{LT}_{50}$ maka semakin cepat laju infeksi yang disebabkan suatu bahan kimia tersebut sehingga semakin rendah nilai $\mathrm{LT}_{50}$ artinya bahan tersebut semakin beracun. ${ }^{21}$ Berdasarkan penelitian yang dilakukan Moehammandi, 22 kondisi morfologi larva uji yang mati memiliki beberapa persamaan yaitu warna gelap dengan kondisi kepala hampir putus.

Hasil uji Mann Whitney, dapat diketahui perbedaan antara dua perlakuan. Nilai yang diperoleh dari uji Mann Whitney mengenai perbedaan efektivitas air perasan kulit jeruk manis dengan temefos, yaitu pada konsentrasi $0,05 \%, 0,2 \%, 0,4 \%$, dan $0,6 \%$ terdapat perbedaan yang signifikan dengan temefos. Sedangkan pada konsentrasi $0,8 \%, 1 \%, 1,2 \%$, dan $1,4 \%$ tidak terdapat perbedaan yang signifikan dengan temefos.

Pemanfaatan beberapa spesies dan bagian jeruk sebagai larvasida didasarkan pada berbagai macam kandungan senyawa kimia, seperti flavonoid dan limonoid. ${ }^{23}$ Berdasarkan skrining fitokimia yang dilakukan Oluremi $\mathrm{dkk},{ }^{12}$ kulit jeruk mengandung tanin, saponin, fitat oksalat, flavonoid, dan limonoid. Kandungan senyawa tanin pada kulit jeruk dapat menghalangi serangga dalam mencerna makanan dan akhirnya mengganggu pertumbuhan serangga. Senyawa flavonoid menyerang sistem pernafasan yang ada pada permukaan tubuh larva dan menimbulkan kelayuan syaraf sehingga tidak mampu bernafas, senyawa limonoid akan menghambat serangga untuk makan seperti halnya tanin (antifeedant). Sedangkan, saponin akan mengganggu perkembangan dan gangguan pergantian kulit pada larva (moulting) sehingga larva tidak akan mampu berkembang ke stadium selanjutnya.

\section{Kesimpulan}

Berdasarkan penelitian yang telah dilakukan, maka kesimpulan yang diambil adalah bahwa air perasan kulit jeruk manis dapat digunakan sebagai larvasida Aedes aegypti dengan konsentrasi paling efektif adalah pada konsentrasi $1 \%$ dan 1,4\% karena kemampuan membunuh larva uji sama dengan temefos, yaitu mampu membunuh $100 \%$ larva uji. Nilai lethal concentration 50 pada konsentrasi $0,731 \%$ dan nilai lethal time 50 pada jam ke 13.211. Efektivitas air perasan kulit jeruk manis pada konsentrasi $0,8 \%, 1 \%, 1,2 \%$, dan 1,4\% tidak memiliki perbedaan yang signifikan dengan temefos $0,01 \%$.

\section{Saran}

Berdasarkan penelitian pengaruh air perasan kulit jeruk manis terhadap larva Aedes aegypti yang telah dilakukan, diperlukan penelitian yang lebih lanjut dari kan- dungan zat dalam kulit jeruk manis terkait zat yang paling dominan berperan sebagai larvasida.

\section{Daftar Pustaka}

1. World Health Organization. Dengue: guidelines for laboratory and field testing of mosquito larvicides. Geneva: World Health Organization; 2005.

2. Soedarto. Buku ajar parasitologi kedokteran. Jakarta: Sagung Seto; 2012

3. Kurane I. Dengue hemorrhagic fever with spesial emphasis on immunopathogenesis. Comparative Immunology, Microbiology \& Infectious Disease. 2007; 30: 329-40.

4. Kementerian Kesehatan Republik Indonesia. Profil kesehatan Indonesia tahun 2013. Jakarta: Kementerian Kesehatan Republik Indonesia; 2014

5. Kementerian Kesehatan Republik Indonesia. Peraturan menteri kesehatan nomor 374 tentang pengendalian vektor. Jakarta: Departemen Kesehatan Republik Indonesia; 2010.

6. Taviv Y, Sikhu A, Sitorus H. Pengendalian DBD melalui pemanfaatan pemantau jentik dan ikan cupang di Kota Palembang; Baturaja. Buletin Penelitian Kesehatan. 2010; 38 (4): 215 - 24.

7. Ridha MR, Nisa K. Larva Aedes aeypti sudah toleran terhadap temepos di Kota Banjarbaru, Kalimantan Selatan. Jurnal Vektora. 2015; 3 (2): 9111.

8. Hartati SY. Prospek perkembangan minyak atsiri sebagai pestisida nabati. Perspektif. 2012; 11 (1): 45-8.

9. Lauwrens, Florensia IJ, Wahongan GJ, Bernadus JB. Pengaruh dosis abate terhadap jumlah populasi jentik nyamuk Aedes sp di Kecamatan Malalayang Kota Manado. Jurnal e-Biomedik. 2014; 2 (1).

10. Ferguson. Medicinal use of citrus [online]. 2014 [cited 2014 Apr 14]. Available from: www.floridaplants.com/Reprints/medicinalcitrus.pdf.

11. Bilal H, Akram W, Ali-Hasan S. Lavicidal activity of citrus limonoids against Aedes albopictus larvae. Journal Arthropos-Borne Disease. 2012; 6(2): 104-11.

12. Oluremi OIA, Ngi J, Andrew IA. Phytonutrients in citrus fruit peel meal and nutritional implication [serial on internet]. Livestock Res Rur Dev for livestock production. 2007 [cited 2014 Aug 6]; 19 (7). Available from: http://www.lrrd.org/lrrd19/7/olur19089.htm

13. Stelljes KB. Questions about citrus limonoids [online]. 2014 [cited 2014 Apr 8]. Available from: http://www.ars.usda.gov/is/pr/1999/ bg990323.htm.

14. Robinson T. Kandungan organik tumbuhan tingkat tinggi. Bandung: ITB; 1991.

15. Chaieb I. Saponins as insecticides: a review. Tunisia. Tunisian Journal of Plant Protection. 2010; 5: 39-50.

16. Wati FA. Pengaruh air perasan kulit jeruk manis (Citrus aurantium sub spesies sinensis) terhadap tingkat kematian larva Aedes aegypti instar III in vitro [skripsi]. Surakarta: Fakultas Kedokteran Universitas Sebelas Maret; 2010

17. Astuti EP, Riyadhi A, Ahmadi NR. Efektivitas minyak jarak pagar sebagai larvasida ati-ovoiposisi dan ovisida terhadap larva nyamuk Aedes albopictus. Buletin Penerbitan Tanaman Rempah dan Obat. 2011; 22 (1): 44-53.

18. Asikin S. Toksisitas tumbuhan jengkol terhadap hama tanaman. Banjarbaru; Badan Penelitian Pertanian Lahan Rawa; 2013.

19. Becker N, Petric D, Zgomba M, Boase C, Madon M, Dahl C, et al. 
Mosquitoes and their control. $2^{\text {nd }}$ ed. Berlin; Heidelberg: SpringerVerlag Berlin Heidelberg; 2010.

20. International Union of Pure Applied Chemistry. Compendium of chemical terminology [e-book]. 2nd ed. (the "Gold Book"). Compiled by McNaught AD, Wilkinson A. Oxford: Blackwell Sci Publ; 1997 [cited 2014 Sept 6]. Available from: http://goldbook.iupac.org

21. Facundo HT, Hirao A, Santiago DR, Gabriel BP. Screening of microbial agents for the control of the orchid lema, Lema pectoralis Baly
(Coleoptera: Chrysomelidae). The Philippine Agricultural. Scientist. 2001; 84:171-8.

22. Moehammadi N. Potensi biolarvasida ekstrak herba Ageratum conyzoides linn. dan daun Saccopetalum horsifieldii benn terhadap larva nyamuk Aedes aegypti L. Jurnal Berkala Penelitian Hayati. 2005; 10.

23. Milind P, Dev C. Orange: range of benefits. International Research Journal of Pharmacy. 2012; 3 (7): 59-63. 